\title{
IJIKMMENA
}

3,2

125

\section{TRANSITION TO A KNOWLEDGE- BASED ECONOMY IN THE ARAB REGION}

\section{Samia Satti Osman Mohamed Nour'}

University of Maastricht, The Netherlands

\begin{abstract}
Purpose: This paper aims to assess the progress in the transition towards knowledge-based economies in the Arab region.

Design/methodology/approach: This paper uses updated secondary data obtained from different sources. It uses both descriptive and comparative approaches and uses the OECD (1996) definition of knowledge-based economy and the World Bank Knowledge Index (KI) and Knowledge Economy Index (KEI) and other indicators often used in the international literature to examine progress towards transition to knowledge-based economies in the Arab region. Findings: The findings support the first hypothesis concerning poor and slow progress in the transition towards knowledge-based economies in the Arab region. The results corroborate the second hypothesis concerning the variation in transition to knowledge-based economies in the Arab region.

Originality/value: This paper is valuable because it fills the gap in the Arab literature by presenting a more comprehensive analysis and investigating recent progress in the transition to knowledge-based economies in the Arab region, since these issues are not adequately discussed in the Arab literature. Moreover, the paper supports the efforts aimed at enhancing knowledgebased economies in the Arab region. The findings imply that it is essential for the Arab region to implement sound and coherent policies to accelerate and enhance the transition to a knowledge-based economy and to achieve sustainable economic development.
\end{abstract}

International Journal of Innovation and Knowledge Management in Middle East \& North Africa Vol. 3 No. 2, 2014

Keywords: Knowledge, Knowledge-based economy, Knowledge Index, Arab region

${ }^{1}$ Dr Samia Satti Osman Mohamed Nour, UNU-MERIT, School of Business and Economics, University of Maastricht, Maastricht, THE NETHERLANDS, 


\section{INTRODUCTION}

This paper aims to assess the progress in the transition towards knowledge-based economies in the Arab region. ${ }^{2}$ This paper addresses the following questions: how important is the progress in the transition to knowledge-based economies in the Arab region, and what are the major policy instruments to facilitate the transition towards knowledgebased economies in the Arab region?

We examine two hypotheses, the first of which concerns the poor and slow progress in the transition towards knowledge-based economies in the Arab region. The second hypothesis concerns the variation in transition to knowledge-based economies in the Arab region.

We fill the gap in the Arab literature by presenting a more comprehensive analysis to improve understanding of the progress in the transition to knowledge-based economies using recent and updated data and provide a more updated study compared to the few earlier studies on the knowledge economy in the Arab region (Nour, 2011a). In contrast to earlier studies in the Arab literature (Nour, 2010; 2011b,c; 2012a,b; 2013a,b), which examine the incidence and existence of knowledge and its transfer, an interesting element in our analysis is that we investigate the recent progress in the transition to knowledgebased economies in the Arab region compared to other world regions. Moreover, we support the efforts aimed at enhancing knowledge-based economies in the Arab region.

Regarding the research method, we used descriptive and comparative methods of analysis. We use the OECD (1996) framework and definition of a knowledge-based economy: economies which are directly based on production, distribution and use of knowledge and information. We also used the World Bank framework and definition of KI and KEI and KEI four pillars related to the knowledge economy: economic incentive and institutional regime, education and human resources, the innovation system and Information and Communication Technology (ICT) pillars.

${ }^{2}$ The Arab region is composed of twenty-two countries, including Algeria, Bahrain, Comoros, Djibouti, Egypt, Iraq, Jordan, Kuwait, Lebanon, Libyan Arab Jamahiriya, Mauritania, Morocco, Oman Occupied Palestine Territories, Qatar, Saudi Arabia, Somalia, Sudan, Syrian Arab Republic, Tunisia, United Arab Emirates and Yemen.

\section{Transition to a} knowledge-based economy in the Arab region 
IJIKMMENA

3,2

127

\section{CONCEPTUAL FRAMEWORK AND LITERATURE REVIEW}

In recent years the world economy has witnessed a fundamental structural change driven by both globalization and the revolution in ICT leading to a new economic system. The new economic system is characterised by the increasing significance of knowledge, the rapid diffusion of ICT, productivity growth and intensified competition and globalization trend. Hence, the role of knowledge has intensified and attracted a great deal of interest at the international level.

Knowledge creation, accumulation and acceleration is intensifying the pace of scientific and technological progress and has been at the heart of the economic growth literature. The definition of knowledge in the literature is based on the distinction between codified and tacit knowledge (Dasgupta and David, 1994), and between embodied flows of knowledge (knowledge incorporated into machinery and equipment) and disembodied flows of knowledge (the use of knowledge transmitted through scientific and technical literature, consultancy, education systems, movement of personnel, etc). Often, investment in knowledge refers to public spending on education, training, R\&D and ICT.

Drucker (1998) argued that "knowledge has become the key economic resource and the dominant-and perhaps the only-source of competitive advantage". Powell and Snellman (2004) defined the knowledge economy as production and services based on knowledge-intensive activities that contribute to an accelerated pace of technical and scientific advance, as well as rapid obsolescence. The key component of a knowledge economy is a greater reliance on intellectual capabilities than on physical inputs or natural resources. ${ }^{3}$ David and Foray (2001) discussed knowledge-based communities as agents of economic change, and found that knowledge-based activities emerge when people, supported by information and communication technologies, interact in concrete efforts to co-produce (i.e. create and exchange) new knowledge and information; communication technologies are intensively used to codify and transmit the new knowledge. Therefore, a knowledge-intensive community is one wherein a large proportion of members are involved in the production and reproduction of knowledge. According to OECD (1996) the term "knowledge-based economy" results from a fuller recognition of the role of knowledge and technology in economic growth. Knowledge, as embodied

${ }^{3}$ See Powell and Snellman (2004), p. 199. 
in human beings (as "human capital") and in technology, has always been central to economic development. OECD (1996) discusses "knowledgebased economies" - economies which are directly based on the production, distribution and use of knowledge and information. The OECD economies are increasingly based on knowledge and information and are more strongly dependent on the production, distribution and use of knowledge than ever before. Indeed, it is estimated that more than 50 per cent of Gross Domestic Product (GDP) in the major OECD economies is now knowledge-based. This is reflected in the trend in OECD economies towards growth in hightechnology investments, high-technology industries, more highly-skilled labour and associated productivity gains. ${ }^{4}$

The World Bank uses Knowledge Index (KI) and Knowledge Economy Index (KEI) to compare knowledge across the world's countries. According to the World Bank, the Knowledge Index (KI) measures a country's ability to generate, adopt and diffuse knowledge. This is an indication of the overall potential of knowledge development in a given country. Methodologically, the KI is the simple average of the normalized key variables in three Knowledge Economy pillars education and human resources, the innovation system and Information and Communication Technology (ICT). The Knowledge Economy Index (KEI) takes into account whether the environment is conducive for knowledge to be used effectively for economic development. It is an aggregate index that represents the overall level of development of a country or region towards the Knowledge Economy. ${ }^{5}$

${ }^{4}$ See OECD (1996), pp. 3, 7, 9, 18-19.

${ }^{5}$ The KEI is calculated based on the average of the normalized performance scores of a country or region on all four pillars related to the knowledge economy: economic incentive and institutional regime, education and human resources, the innovation system and ICT. The economic incentive and institutional regime pillar includes tariff and nontariff barriers, regulatory quality and rule of law. The education and human resources pillar includes average years of schooling, secondary enrollment and tertiary enrollment. The innovation system pillar includes royalty and license fees payments and receipts, patent applications granted by the US Patent and Trademark Office and scientific and technical journal articles. The Information and Communication Technology (ICT) pillar includes fixed telephones, mobile and internet users. For the purposes of calculating $\mathrm{KI}$ and $\mathrm{KEI}$, each pillar is represented by three key variables, see (www.worlbank.org): See the World Bank- KEI, 2012: http://siteresources.worldbank.org/INTUNIKAM/Images/KElindex.jpg.
Transition to a knowledge-based economy in the Arab region 
IJIKMMENA 3,2

According to the World Bank (2011) the term Knowledge Economy has been coined to reflect this increased importance of knowledge. The framework for a knowledge-based economy consists of four pillars to help countries articulate strategies for their transition to a knowledge economy: economic incentives regime, education and human resources, the innovation system and information and communication technology (ICT). Making effective use of knowledge in any country requires the development of appropriate policies, institutions, investments and coordination across the four functional areas. ${ }^{6}$ According to OECD (1996) government policies-particularly those relating to science and technology, industry and education - will need a new emphasis in knowledge-based economies. Acknowledgement is needed of the central role of the firm, the importance of national innovation systems and the requirements for infrastructures and incentives which encourage investments in research and training. Among the priorities, special emphasis should be given to enhancing knowledge diffusion, upgrading human capital and promoting organisational change. Governments can provide the conditions and enabling infrastructures for these changes through appropriate financial, competition, information and other policies. ${ }^{\text {? }}$

Within this framework, the analysis of transition to a knowledgebased economy has been an exciting and interesting recent research issue that has received increasing interest amongst economists. Few studies in the Arab literature show the weak knowledgebased economies in the Arab region (cf. UNDP-AHDR, 20022013; UNDP-MBRF-Arab Knowledge Report, 2009; 2010-2011, Nour, 2010; 2013b,c). Analysis of progress in the transition to a knowledge-based economy in the Arab region is both relevant and important in view of the recent changes and increasing interest in knowledge economies in the Arab region. This increasing interest in the transition to a knowledge-based economy in the Arab region is the major motivation behind this study. Therefore, it might be interesting in this paper to improve understanding and support policy aims to accelerate the transition towards a knowledge-based economy in the region.

6 See the World bank (2011) "Knowledge for Development" accessed January 23, 2013.

${ }^{7}$ See OECD (1996), pp. 3, 7, 9, 18-19. 


\section{GENERAL SOCIO-ECONOMIC CHARACTERISTICS OF THE ARAB REGION}

Based on the above framework and before examining progress in the transition to the knowledge based economy, in this section it is useful to begin with the general socio-economic characteristics of the Arab region. Table 1 shows the general socio-economic and development characteristics of the Arab region and world regions as measured by economic growth (GNI per capita), life expectancy, mean years of schooling, literacy rate and gross enrolment ratios. Table 1 illustrates the substantial gap between Arab and other world regions in terms of population, standard of economic development as measured by GNI per capita and human development index. In general, the Arab region is characterised by low standards of economic development together with high population numbers. According to the World Bank classification of economies, the majority of the Arab countries are classified among medium-income economies. In addition, according to the classification of the UNDP-HDI, the average GDP per capita for the Arab region is classified among the world's medium-income group and is, on average, lower than for those of the other world regions. Furthermore, the other HDI components: average life expectancy, mean years of schooling, expected years of schooling, literacy rate and gross enrolment ratios for the Arab region on average are lower than for those of the world's countries. Moreover, the Arab region is comparable to other developing countries and regions in terms of the widespread and high rates of both unemployment and poverty. These general socio-economic development characteristics of the Arab region have serious implication in that they impose challenges and impede the transition to knowledgebased economies in the Arab region.

Despite the great heterogeneity in economic and development indicators/performance across the Arab countries, it is evident that none of them present a coherent performance and progress in the transition to knowledge-based economies. While the rich Arab Gulf oil economies are leading the Arab states in terms of GDP per capita, human development indicators, knowledge indicators, spending and diffusion of ICT, they fail to make a coherent transition to a knowledgebased economy due to heavy reliance on oil and an unpredictable and volatile trend in growth rates coupled with increasing unemployment, insignificant economic impacts of ICT and limited $R \& D$ activities, a deficient educational system, lack of local technological capabilities, poor capacity for innovation, and lack of local skills.

\section{Transition to a knowledge-based economy in the Arab region}




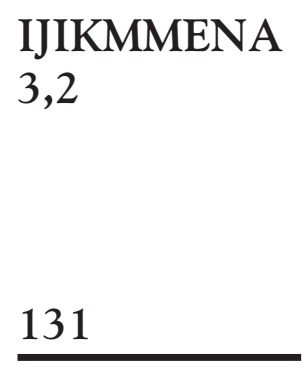

Table I. General socio-economic characteristics of the Arab region compared to other world regions (2002-20I2)

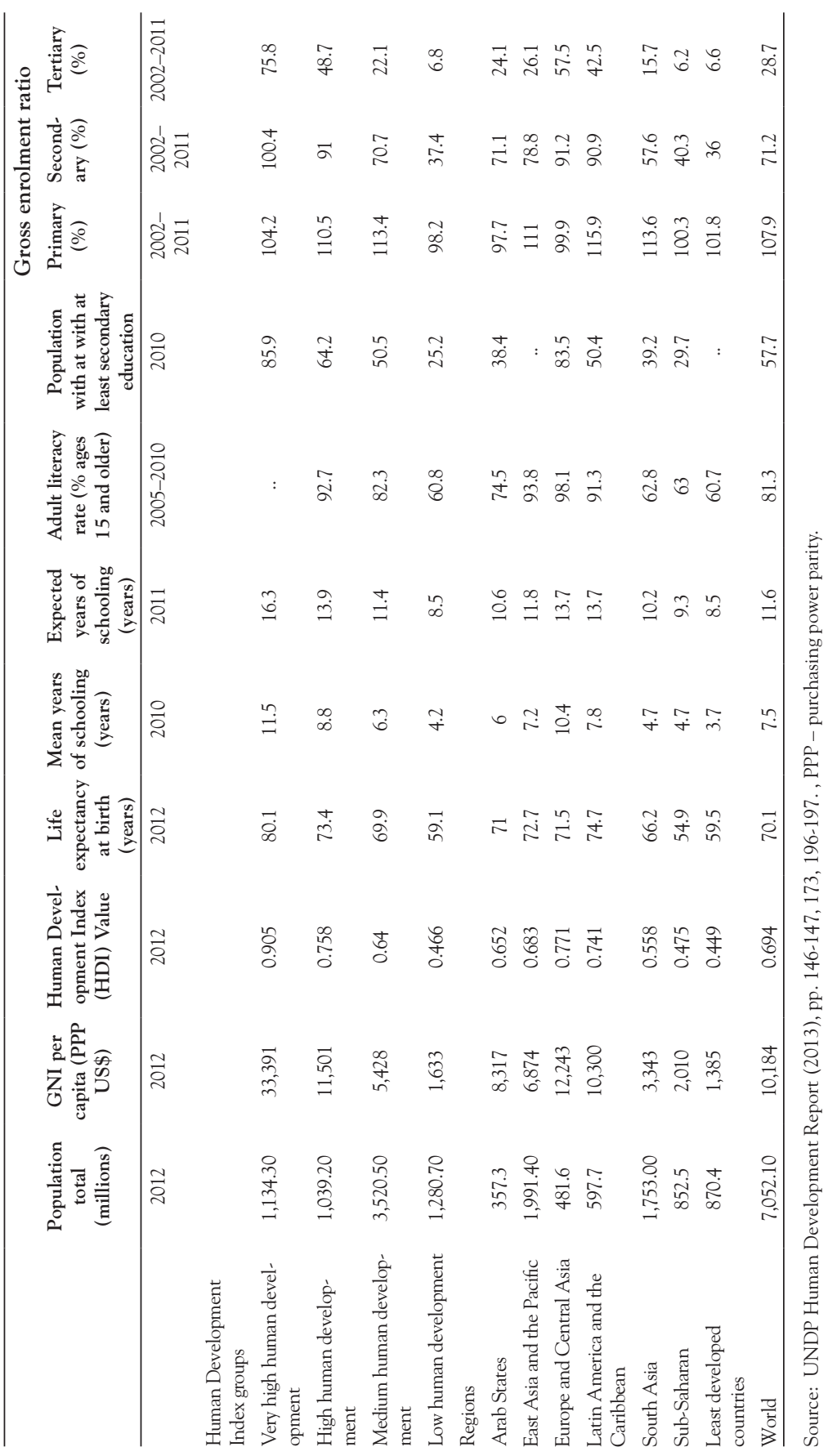




\section{THE DEVELOPMENT OF A KNOWLEDGE-BASED ECONOMY IN THE ARAB REGION}

Based on the above background, this section discusses the research questions and hypotheses concerning the progress in transition to knowledge-based economies in the Arab region. More specifically, we discuss the progress in transition to knowledge based economies in the Arab region using the OECD (1996) definition of a knowledgebased economy and the World Bank Knowledge Index and Knowledge Economy Index.

The progress in transition to knowledge-based economies appears from the World Bank Knowledge Index (KI) and the Knowledge Economy Index (KEI) over the period (1995-2012). ${ }^{8}$ Mainly, KI implies poor progress and the limited ability of the Arab region to generate, adopt and diffuse knowledge; it indicates poor potential of transition to knowledgebased economies in the Arab region. The poor KI reflects poorness with respect to the key variables in three KI pillars: education and human resources, innovation systems and information and communication technology (ICT). The poor performance in terms of KEI implies that the environment is not conducive for the transition to knowledge economies and for knowledge to be used effectively for economic development, and this reflects the constraint in the overall level of development of the Arab region that hinders the transition to knowledge-based economies. The KEI reflects the poor performance of the Arab region on all four pillars related to the knowledge economy: economic incentive and institutional regime, education and human resources, innovation systems and ICT. The declining trends over the period 1995-2012 and small increasing trend over the period 2000-2012 imply poor performance of both the $\mathrm{KEI}$ and KI. Both the economic incentive and institutional regime and education show slight improvement over the period 1995-2012. Both innovation and ICT show slight deterioration over the period 19952012, and slight deterioration over the period 1995-2000 that turned into slight improvement over the period 2000-2012 (see Table 2). These results support our first hypothesis concerning the poor and slow progress in transition to knowledge-based economies in the Arab region, and coincides with a substantial knowledge gap compared to other world regions. Differences in progress in the transition to knowledge-based economies across the Arab countries also appear in terms of KEI and

${ }^{8}$ For the purposes of calculating KI and KEI, each pillar is represented by three key variables. See the World Bank website: $\underline{w w w . w o r l d b a n k . o r g}$

\section{Transition to a knowledge-based economy in the Arab region}


IJIKMMENA KI and all four pillars related to the knowledge economy (economic 3,2 incentive and institutional regime, education and human resources, the innovation system and ICT) over the period 1995-2012. According to the World Bank's Knowledge Index, the United Arab Emirates (UAE) is ranked at the top in the Arab region and is ranked at 42nd in the world, while Djibouti is ranked at the bottom in the Arab countries and 139 among the world's countries. The UAE is ranked first, followed by Bahrain, Oman, Saudi Arabia, Qatar and Kuwait respectively.

The trend in terms of performance as measured by ranking of countries over the period 2000-2012 implies a slight improvement in seven Arab countries, namely: Saudi Arabia (26), Oman (18), Algeria (14), Tunisia (9), the UAE (6), Yemen (6), and Sudan (1), respectively. Slight deterioration is reported in nine Arab countries, namely, Kuwait (18), Jordan (18), Lebanon (13), Morocco (10), Egypt (9), Qatar (5), Djibouti (3), Bahrain (2) and Syria (1) respectively. The UAE is ranked at the top in the Arab region in terms of the Knowledge Index and knowledge economy and innovation system pillar, Bahrain is ranked at the top in the Arab region in terms of education and the human resources indicators pillar and the ICT pillar, and Qatar is ranked at the top in the Arab region in terms of the economic incentives and institutional system pillar. These results support the second hypothesis concerning the variation in knowledge indicators in the Arab region. This implies that the relative improved progress was achieved by Arab Gulf oil economies followed by the diversified economies, mixed oil economies and primary export economies respectively (see Table 2).

The poor progress in transition to knowledge-based economies also appears from the poor progress in terms of the Global Innovation Index (GII) and innovation efficiency index issued by the (INSEAD) for the years 2011-2012, that appear in the value and ranking of the global indicators of innovation related to knowledge in the Arab region compared to other regions of the world. For instance, the performance concerning GII value and ranking over the period 2011-2012 implies that Qatar maintains its 2011 top position in the Arab region.

The GII Report (2012) implies that Qatar is ranked at the top in the Arab region and is ranked 33 globally, followed by the United Arab Emirates, ranked 37 globally, Bahrain, ranked 41 globally, Oman, ranked 47 globally, Saudi Arabia, ranked 48 globally, and then Kuwait, ranked 55 globally. While four Arab countries-Sudan (141), Yemen 


\begin{tabular}{|c|c|c|c|c|c|c|c|c|c|c|c|c|c|c|c|c|}
\hline U & 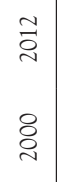 & & $\stackrel{\infty}{+}$ & $F$ & F & $\stackrel{\imath}{\sim}$ & gr & f & in & $\infty$ & $\stackrel{\infty}{\infty}$ & $\stackrel{ }{=}$ & $\tilde{a}$ & $\widetilde{\Xi}$ & $\begin{array}{l}\Xi \\
\Xi\end{array}$ & $\begin{array}{r}\text { Transition to a } \\
\text { knowledge-based } \\
\text { economy in the } \\
\text { Arab region }\end{array}$ \\
\hline 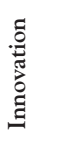 & 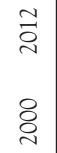 & & $\begin{array}{l}\text { ta } \\
\text { bे } \\
\text { in }\end{array}$ & $\begin{array}{l}n \\
\infty \\
0 \\
0\end{array}$ & $\begin{array}{l}\stackrel{ \pm}{\sigma} \\
\stackrel{\infty}{\sim} \\
\stackrel{\infty}{\sim}\end{array}$ & $\begin{array}{l}\stackrel{\circ}{\circ} \\
\text { in } \\
\stackrel{+}{+}\end{array}$ & $\begin{array}{l}\text { के } \\
\text { in }\end{array}$ & $\begin{array}{l}\tilde{\imath} \\
\text { in } \\
\stackrel{0}{0}\end{array}$ & 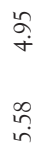 & 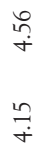 & $\begin{array}{l}\stackrel{゚}{\sim} \\
\stackrel{+}{+}\end{array}$ & $\begin{array}{l}\infty \\
\infty \\
i\end{array}$ & $\begin{array}{l}\stackrel{\infty}{\sim} \\
\stackrel{n}{~} \\
\stackrel{\sim}{\sim}\end{array}$ & $\begin{array}{l}\vec{\sigma} \\
\dot{m} \\
\stackrel{+}{\dot{m}}\end{array}$ & $\begin{array}{l}\underset{\sim}{\sim} \\
i \\
\text { L } \\
i \\
\sim\end{array}$ & 134 \\
\hline 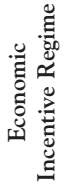 & 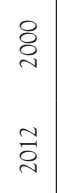 & & రి & $\underset{\leftarrow}{\vec{\sigma}}$ & $\begin{array}{l} \\
\infty \\
\infty \\
\text { in }\end{array}$ & $\underset{+}{ \pm}$ & đ̛̣ & $\underset{\text { iี }}{\tilde{N}}$ & $\stackrel{n}{\circ}$ & $\hat{\alpha}$ & $\stackrel{\triangleright}{\stackrel{\circ}{+}}$ & 峁 & $\underset{F}{F}$ & $\underset{\sigma}{\tilde{r}}$ & $\underset{\sim}{\tilde{m}}$ & \\
\hline 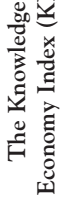 & $\stackrel{\stackrel{\sim}{\sim}}{\stackrel{\sim}{*}}$ & & no & oे & $\stackrel{\circ}{\circ}$ & $\begin{array}{l}\infty \\
\stackrel{\infty}{0} \\
\text { in }\end{array}$ & $\begin{array}{l}\tilde{\infty} \\
0 \\
0\end{array}$ & $\begin{array}{l}\infty \\
\infty \\
i n\end{array}$ & $\stackrel{\text { in }}{\stackrel{+}{*}}$ & $\begin{array}{l}\vec{\infty} \\
\dot{n}\end{array}$ & $\stackrel{\infty}{\stackrel{\sim}{+}}$ & $\tilde{\vec{i}}$ & $\stackrel{\sim}{+}$ & $\begin{array}{l}\stackrel{\circ}{\circ} \\
\stackrel{+}{ }\end{array}$ & $\underset{i}{\stackrel{J}{i}}$ & \\
\hline 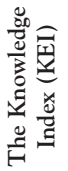 & $\begin{array}{l}\text { 尺े } \\
\text { ஓे }\end{array}$ & & $\begin{array}{l}\underset{+}{+} \\
\stackrel{\sim}{\sim}\end{array}$ & $\underset{\stackrel{\overbrace{}}{\sim}}{\stackrel{2}{\sim}}$ & 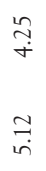 & $\underset{\text { in }}{\stackrel{q}{\text { in }}}$ & 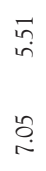 & $\underset{r}{\stackrel{\partial}{r}}$ & $\underset{\text { in }}{\stackrel{\sim}{*}}$ & $\stackrel{+}{\stackrel{r}{*}}$ & 守 & $\vec{m}$ & $\underset{\sim}{\sim}$ & $\stackrel{n}{\dot{m}}$ & $\begin{array}{l}\hat{n} \\
\tilde{m} \\
\infty \\
\stackrel{\infty}{m}\end{array}$ & \\
\hline $\begin{array}{l}\text { है } \\
\text { 气ूँ }\end{array}$ & 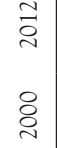 & & $\begin{array}{l}\text { oे } \\
\text { r. } \\
\text { ஜ̊. } \\
\text { in }\end{array}$ & $\begin{array}{l}\stackrel{\infty}{\sigma} \\
\stackrel{0}{0} \\
\stackrel{0}{0}\end{array}$ & $\begin{array}{l}\tilde{\infty} \\
\stackrel{n}{n} \\
\tilde{n} \\
\stackrel{n}{\sim}\end{array}$ & 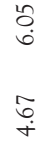 & $\begin{array}{l}\vec{\infty} \\
\text { in }\end{array}$ & $\begin{array}{l}\text { in } \\
\text { in } \\
\infty \\
\infty \\
\infty \\
\text { in }\end{array}$ & $\begin{array}{l}\underset{+}{+} \\
\infty \\
\stackrel{\infty}{0} \\
\text { in }\end{array}$ & $\begin{array}{l}\stackrel{\infty}{+} \\
\stackrel{+}{+}\end{array}$ & 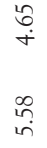 & $\underset{j}{+}$ & $\begin{array}{l}\stackrel{+}{\mathrm{m}} \\
\text { ro } \\
\stackrel{\overrightarrow{+}}{+}\end{array}$ & $\begin{array}{l}\stackrel{\sim}{m} \\
\stackrel{m}{m}\end{array}$ & $\begin{array}{l}\vec{\rho} \\
\vec{m} \\
\stackrel{\sim}{n}\end{array}$ & \\
\hline 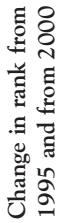 & ৪ి & & 0 & in & $\stackrel{\infty}{\sim}$ & $\stackrel{\sim}{\sim}$ & in & $\stackrel{\infty}{\longrightarrow}$ & $\stackrel{\infty}{\longrightarrow}$ & $a$ & $\stackrel{?}{\rightarrow}$ & \pm & $\neg$ & $\stackrel{ }{7}$ & 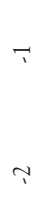 & \\
\hline 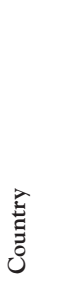 & & 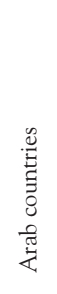 & 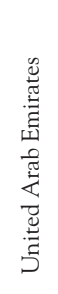 & 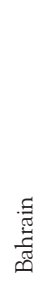 & $\begin{array}{l}\text { ‡్: } \\
\text { ठี }\end{array}$ & 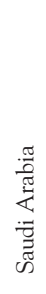 & 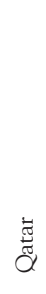 & 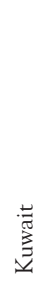 & $\begin{array}{l}\text { 丞 } \\
\stackrel{0}{0}\end{array}$ & 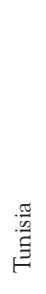 & 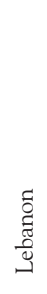 & $\begin{array}{l}\frac{\pi}{\vec{L}} \\
\frac{\mathrm{g}_{0}}{\varangle}\end{array}$ & $\begin{array}{l}\overrightarrow{\sigma_{0}} \\
\overrightarrow{\sigma_{0}}\end{array}$ & 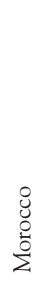 & 袩 & $\begin{array}{l}\text { Table } 2 \text {. The } \\
\text { Knowledge Index } \\
(\mathrm{KI}) \text { and Knowledge } \\
\text { Economy index (KEI) } \\
\text { in the Arab region } \\
\text { and world regions } \\
(2000-20 \mathrm{I} \text { ) }\end{array}$ \\
\hline
\end{tabular}


IJIKMMENA ‡ 3,2

\section{5}

$$
\begin{aligned}
& \stackrel{\infty}{\beth} \stackrel{\sim}{=} \stackrel{0}{=}
\end{aligned}
$$

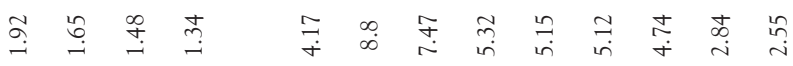

135

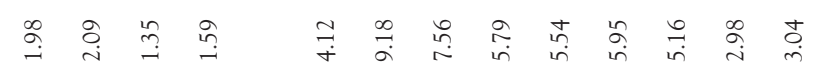

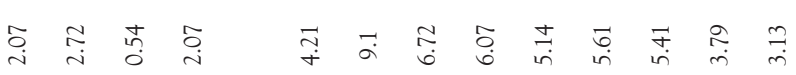

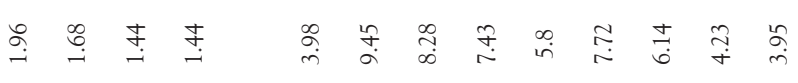

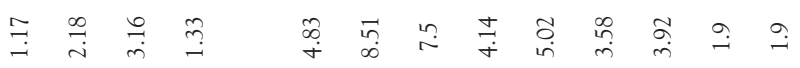

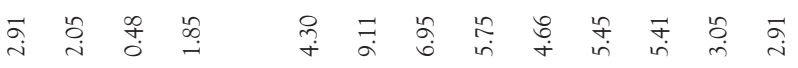

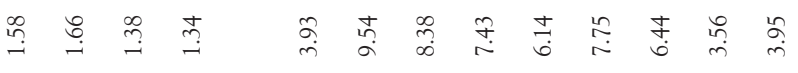

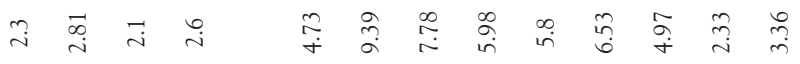

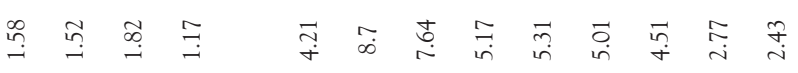

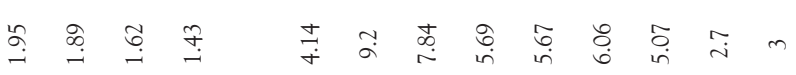

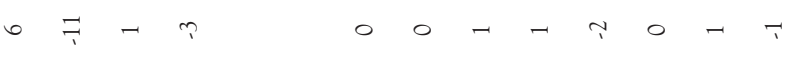
$+\quad \neg \vec{\uparrow} \quad-\infty \neg-\uparrow-\uparrow-$

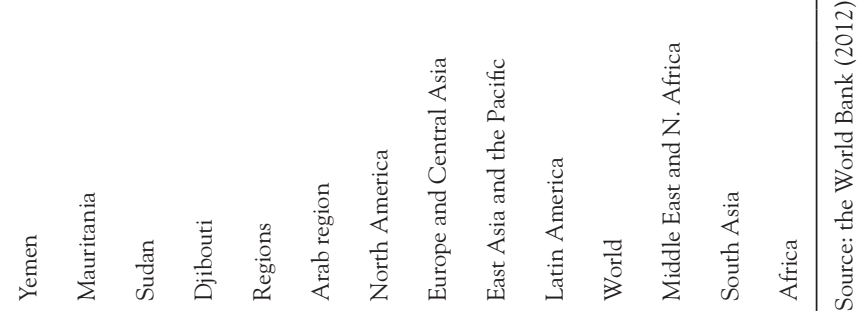


(139), Syria (132) and Algeria (124)—occupied the four bottom places regionally, Sudan and Yemen occupied the bottom and third bottom places globally in the International Classification respectively. Difference in performance within the Arab region appears from the fact that the top performance in Qatar is about three times that of the bottom in Sudan. The trend over the period 2011-2012 implies that the performance has improved in the majority of Arab countries, namely, Algeria (5), Oman (4), Bahrain (3), Saudi Arabia (3), Tunisia (3), the United Arab Emirates (2), Morocco (2) and Kuwait (1), while it has deteriorated in Egypt (-1), Lebanon (-1), Jordan (-1), Qatar (-2), Yemen (-2), Syria (-2), and Sudan $(-4)$. The trend in the Global Innovation Index ranking over the period 2011-2012 implies that the ranking performance of countries has improved in Oman (10), Tunisia (7), Saudi Arabia (6), Morocco (6), Bahrain (5) and Algeria (1), while, the rank has deteriorated in the United Arab Emirates (-3), Kuwait (-3), Qatar (-7), Lebanon (-12), Jordan (-15), Egypt (-16), Yemen (-16), Syria (-17) and Sudan (-17), respectively (see Table 3 ).

The Global Innovation Index shows the disparity in the performance of the Arab countries concerning some indicators associated with knowledge absorption, creation, impact and diffusion. For instance, the performance regarding knowledge absorption implies that Qatar is ranked at the top, followed by Algeria, Saudi Arabia, Lebanon, Oman and the United Arab Emirates, while Syria followed by Sudan are ranked at the bottom. The difference in performance within the Arab region appears from the fact that the top performance in Qatar is about four times that of the bottom in Syria. The trend over the period 2011-2012 implies a slight improvement in performance in the majority of the Arab countries, namely, the UAE (19), Kuwait (15), Algeria (10), Saudi Arabia (6), Yemen (4), Bahrain (4), Morocco (1) and Syria (1), while it implies a slight deterioration in the performance of Tunisia (-0.1), Oman (-1), Egypt (-1), Jordan (-7), Lebanon (-8) and Sudan (-22), (see Table 3$)$.

Moreover, the performance concerning knowledge creation implies that the UAE is ranked at the top, followed by Tunisia and Oman, while Yemen followed by Qatar are ranked at the bottom. The difference in performance within the Arab region appears from the fact that the top performance in UAE is about 24 times that of the bottom in Yemen. The trend over the period 2011-2012 implies a slight improvement in performance in the majority of the Arab countries, namely, the United

\section{Transition to a} knowledge-based economy in the Arab region 


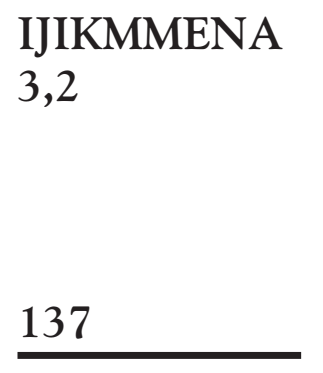

Table 3.Global Innovation Index, Knowledge Indicators, capacity for innovation and localization of technology index and technological infrastructure rankings in the Arab region (2009-20I2)

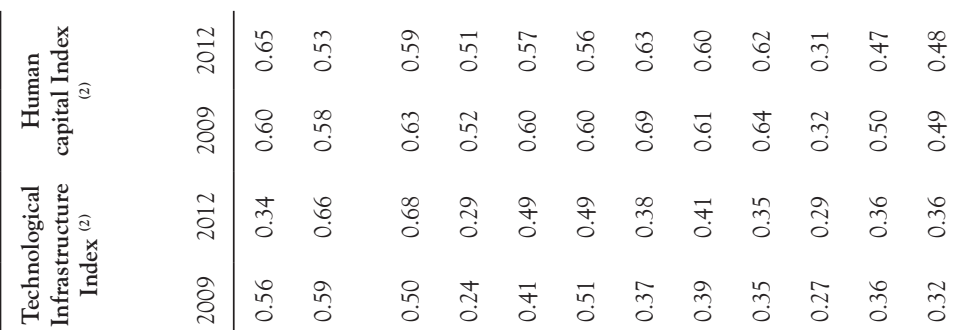

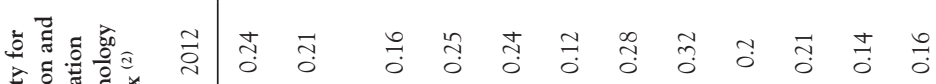

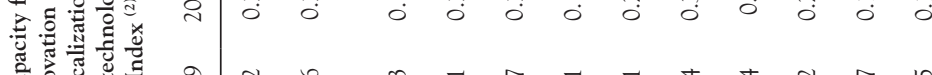

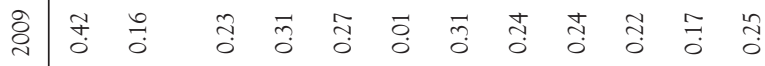

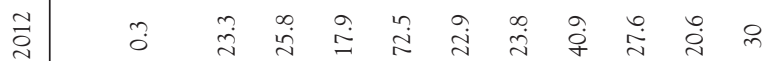

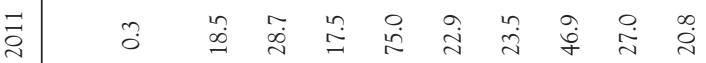

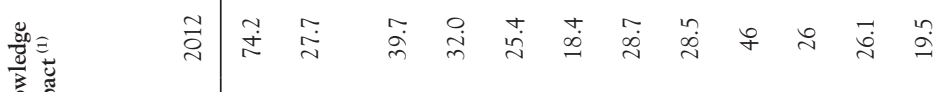

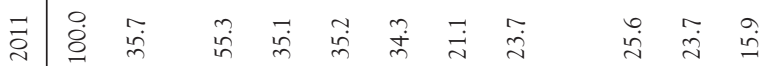

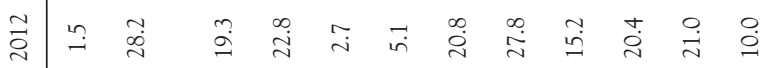

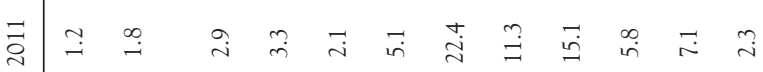

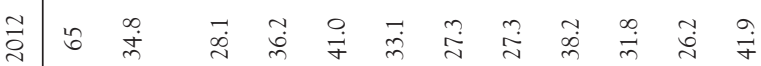

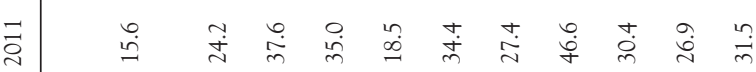

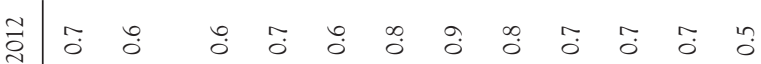

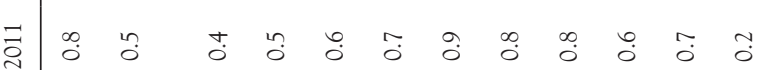

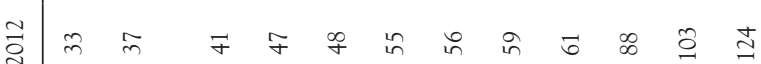

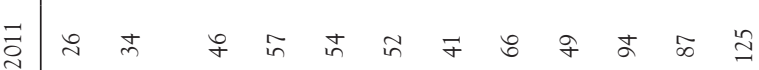

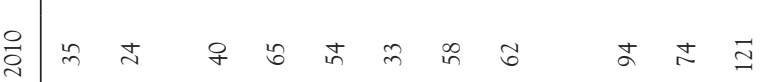

ర్తి d ¿

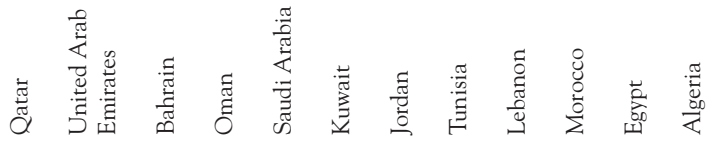




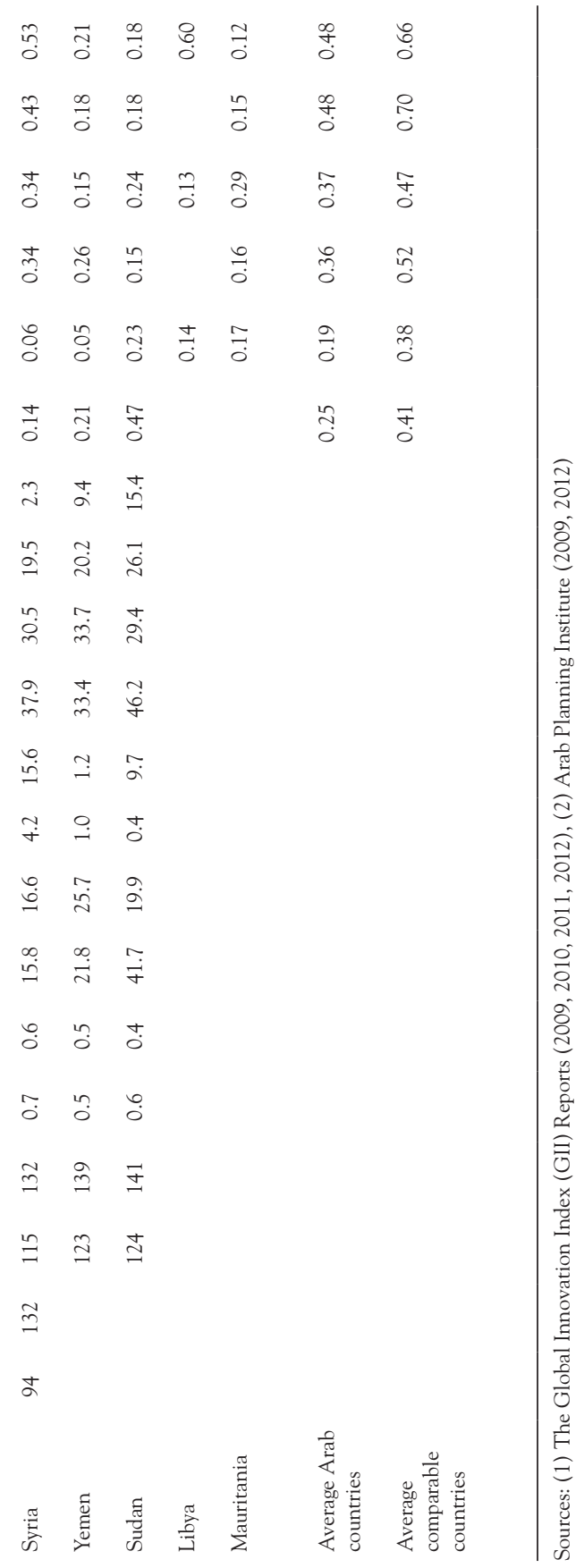

Transition to a knowledge-based economy in the Arab region

138 
IJIKMMENA Arab Emirates (26.4), Tunisia (16.5), Oman (19.5), Bahrain (16.4), 3,2

Morocco (14.6), Egypt (13.9), Syria (11.4), Sudan (9.3), Algeria (7.7), Saudi Arabia (0.6), Qatar (0.3) Yemen (0.2), and Lebanon (0.1). There has been no change in Kuwait (0), while slight deterioration has taken place in the performance only in Jordan (-1.6) (see Table 3).

In addition, the performance regarding knowledge impact implies that Qatar is ranked at the top, followed by Lebanon and Bahrain, whereas, Kuwait, Algeria and Saudi Arabia are ranked at the bottom. The difference in performance within the Arab region appears from the fact that the top performance in Qatar is about four times that of the bottom in Kuwait. The trend over the period 2011-2012 implies slight improvement in the performance in a few Arab countries, namely, Lebanon (46), Jordan (8), Tunisia (5), Algeria (4), Egypt (2) and Yemen (0.3), while it implies slight deterioration in the performance in the majority of Arab countries, namely, Morocco (-0.1), Oman (-3), Syria $(-7)$, United Arab Emirates (-8), Saudi Arabia (-10), Bahrain (-16), Kuwait (-16), Sudan (-17) and Qatar (-26) (see Table 3).

Furthermore, the performance concerning knowledge diffusion implies that Kuwait is ranked at the top, followed by Lebanon and Algeria, while United Arab Emirates followed by Syria and Yemen are ranked at the bottom. The difference in the performance within the Arab region appears from the fact that the top performance in Kuwait is about 242 that of the bottom in UAE. The trend over the period 2011-2012 implies slight improvement in the performance in some Arab countries, namely, Algeria (30), Bahrain (5), Morocco (1), Saudi Arabia (0.4) and Tunisia (0.3). There has been no change in United Arab Emirates (0) and Jordan (0), while slight deterioration has taken place in the performance in Egypt (-0.2), Oman (-3), Kuwait (-3), Lebanon (-6), Yemen (-11), Sudan (-11), and Syria (-17) (see Table 3).

Finally, the poor progress in transition to knowledge-based economies also appears from the poor progress in terms of capacity for innovation and localization of technology index, technological infrastructure and human capital (see Table 3). The average for Arab countries implies slight deterioration in terms of capacity for innovation and localization of technology index from 0.25 in 2009 to 0.19 in 2012. The average for Arab countries implies slight improvement in terms of technological infrastructure indicators from 0.36 in 2009 to 0.37 in 2012. The average for Arab countries implies stagnation with no 
change in terms of human capital indicators that accounted for 0.48 in 2009 and 2012 (see Table 3).

Our findings imply slight improvement in the performance concerning progress in the transition to knowledge-based economies in both the UAE and Qatar compared to other countries in the Arab region. For instance, Qatar has strength in knowledge absorption and knowledge impact, while, UAE has strength in infrastructure, notably, ICT infrastructure. Both Qatar and UAE maintain their 2011 top first and second positions in GII in the Arab region. They come at the top in most GII pillar and sub-indicators, but with the exception of a few indicators, they show relative weaknesses. For instance, Qatar shows relative weaknesses in its knowledge and technology outputs and capacity to knowledge creation as captured by its relatively poor showing in the scientific and technical articles, and weakness in knowledge diffusion as captured by its relatively poor showing high-tech exports. While the UAE shows relative weaknesses in its knowledge diffusion as captured by its relatively poor showing in the high-tech exports, and weakness in knowledge impact as captured by knowledge and technology outputs as captured by scientific and technical articles. Our results also imply that the application of the OECD (1996) definition of knowledge-based economies (economies which are directly based on production, distribution and use of knowledge and information) implies a slight improvement in the performance concerning progress in the transition to knowledge-based economies that appears from a slight improvement in knowledge creation, knowledge absorption, knowledge diffusion and knowledge impact in the majority of Arab countries (see Table 3).

Therefore, our results in this section support the first hypothesis concerning the poor and slow progress in transition toward knowledgebased economies in the Arab region. Our results corroborate the second hypothesis concerning the variation in transition to knowledge-based economies in the Arab region.

\section{CONCLUSIONS}

In this paper we present an overview and assessment of progress in transition to knowledge-based economies in the Arab region and we contribute to recently published research studies that aim to improve understanding of the progress in this field.

\section{Transition to a knowledge-based economy in the Arab region}


IJIKMMENA 3,2

This paper employs both descriptive and comparative approaches and uses the OECD (1996) framework and definition of a knowledge-based economy and the World Bank framework and definition of Knowledge Index (KI) and Knowledge Economy Index (KEI) and other related knowledge indicators used in the literature to examine the progress in transition to knowledge-based economies in the Arab region. We fill the gap in the Arab literature by presenting a more comprehensive analysis to improve understanding of the progress in the transition to knowledgebased economies using recent and updated data and provide a more updated study compared to earlier studies in this field. In contrast to earlier studies in the Arab literature that examine the incidence and existence of knowledge and transfer of knowledge, an interesting element in our analysis is that we investigate the recent progress in the transition to knowledge-based economies in the Arab region compared to other world regions. Moreover, we support the efforts aimed at enhancing the knowledge-based economies in the region.

Our results in this section support the first hypothesis concerning the poor and slow progress in transition toward knowledge-based economies in the Arab region. Our results corroborate the second hypothesis concerning the variation in transition to knowledge based economies in the region.

Our results therefore imply that it is essential for the Arab region to implement sound and coherent policies to accelerate and enhance the transition to a knowledge-based economy and to achieve sustainable economic development in the Arab region. This will be achieved by investing heavily in education and training, boosting innovation through intensive research and development, developing a modern and accessible information infrastructure, and creating stable and enabled economic and institutional regimes and environments conducive to the transition to knowledge-based economies in the Arab region.

\section{ACKNOWLEDGEMENTS}

The research work presented in this paper was originally prepared for the World Association for Sustainable Development (WASD) 2013 Annual Conference: "10 YEARS OF SUSTAINABLE DEVELOPMENT: New Multi-Disciplinary Approaches and Methodologies", The London School of Economics and Political Science (LSE), 2-4 September 2013, London, United Kingdom. The author would like to thank 
the participants for their useful comments on this paper. All the usual disclaimers apply.

\section{REFERENCES}

Arab Planning Institute (2012), Arab Competitiveness Report, Fourth Edition, Kuwait, pp. 51-53, Tables 13-14.

Arab Planning Institute (2009), Arab Competitiveness Report, Third Edition, Kuwait, p. 46, Table 13.

Dasgupta, P. and David, P. (1994), "Toward a new economics of science", Research Policy, Vol. 23 No. 5, pp. 487-521.

David, P.A. and Foray, D. (2001), "An Introduction To the Economy of the Knowledge Society", December 2001. MERIT -Infonomics Research Memorandum Series No. 2001- 041.

Drucker, P. (1998), "From Capitalism to Knowledge Society," in D. Neef (ed.) The Knowledge Economy, Woburn MA: Butterworth, p. 15.

Mohammed bin Rashid Al Maktoum Foundation (MBRF) and the United Nations Development Programme/Regional Bureau for Arab States (UNDP/RBAS) (2009), Arab Knowledge Report 2009, "Towards productive intercommunication for knowledge", Dubai: Al Ghurair Printing and Publishing House, LLC p. 189.

Mohammed bin Rashid Al Maktoum Foundation (MBRF) and the United Nations Development Programme/Regional Bureau for Arab States (UNDP/RBAS) (2010-2011), Arab Knowledge Report 20102011, "Preparing Future Generations for the Knowledge Society", Dubai: Al Ghurair Printing and Publishing House, LLC.

Nour, S. (2010), "The incidence and transfer of knowledge in the Arab countries", UNU-MERIT Working Paper 2010-064, Maastricht, the Netherlands, December 2010: http:/www.merit.unu.edu/ publications/wppdf/2010/wp2010-064.pdf.

Nour, S. (2011a), “Arab Regional Systems of Innovation: Characteristics and Implications”, UNU-MERIT Working Paper 2011-058, Maastricht, the Netherlands, October 2011: http://www.merit.unu. edu/publications/wppdf/2011/wp2011-058.pdf

Nour, S. (2011b), "Arab Spring: Will more freedom boost knowledge transfer?" the United Nations University Headquarters (UNU-HQ), Academic Feature Article, Science, Technology and Society Theme,

Transition to a knowledge-based economy in the Arab region

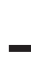


IJIKMMENA

3,2
UNU-HQ, Tokyo, Japan, June 14, 2011: http://unu.edu/articles/ science-technology-society/knowledge-transfer-in-arab-world.

Nour, S. (2012a), "Overview of Knowledge Transfer in the MENA Countries-Egypt", Consultancy Research Report prepared for the European Investment Bank, (EIB, Luxemburg) unpublished consultancy research report, April 2012.

Nour, S. (2012b), "The Incidence and Transfer of Knowledge within the Arab Societies", Paper accepted for publication (paper first published online: 11 January 2012) and forthcoming in the Journal of the Knowledge Economy, 2012, to be published by Springer, Germany, Vol. 3, 2012.

Nour, S. (2013a), "Overview of knowledge economy in the Arab region", Paper accepted for publication (to be first published online April 2013) and forthcoming in the Journal of the Knowledge Economy, 2013, to be published by Springer, Germany, Vol. 4, 2013.

Nour, S. (2013b), "Overview of knowledge economy in the Arab region", UNU-MERIT Working Paper 2013-015, Maastricht, the Netherlands, January 2013. http://www.merit.unu.edu/publications/ wppdf/2013/wp2013-015.pdf

Nour, S. (2013c), "Regional systems of innovation in the Arab region”, UNU-MERIT Working Paper 2013-012, Maastricht, the Netherlands, January 2013: http://www.merit.unu.edu/publications/ wppdf/2013/wp2013-012.pdf

Organisation For Economic Co-Operation And Development OECD (1996), "The Knowledge-Based Economy", GENERAL DISTRIBUTION OECD/GD(96)102, OECD, 1996: http://www. oecd.org/science/sci-tech/1913021.pdf., pp. 3, 7, 9, 18-19.

Powell, W. and Snellman, K. (2004), "The Knowledge Economy", Annual Review Sociology, Vol. 30, pp. 199-220.

The Global Innovation Index Report (2009), NSEAD, Fontainebleau, France.

The Global Innovation Index Report (2010), NSEAD, Fontainebleau, France.

The Global Innovation Index Report (2011), NSEAD, Fontainebleau, France.

The Global Innovation Index Report (2012), NSEAD, Fontainebleau, France. 
The World Bank (2011), "Knowledge for Development" accessed January 23, 2013. http://web.worldbank.org/WBSITE/EXTERNAL/WBI/ WBIPROGRAMS/KFDLP/O,,contentMDK:20269026 menuPK:461 205 pagePK:64156158 piPK:64152884 theSitePK:461198,00.html

The World Bank (2012), "World Development Indicators Database", accessed on October 10, 2012: http://info.worldbank.org/etools/ kam2/KAM_page5.asp\#c103.

United Nations Development Programme (UNDP) Arab Human Development Report (AHDR) (2002), UNDP Arab Human Development Report (2002), "Creating opportunities for future generations", The UNDP. New York: Icons Printing Services.

United Nations Development Programme (UNDP) Arab Human Development Report (AHDR). (UNDP-AHDR) (2003), Arab human development report 2003: Building a knowledge society. Amman, Jordan: UNDP-RBAS; New York, NY: National Press. pp. 5-6, 109-113.

United Nations Development Programme (UNDP) Arab Human Development Report (AHDR) (2009) Arab human development report 2009: Challenges to Human Security in the Arab Countries, Amman, Jordan: UNDP-RBAS; New York, NY: National Press.

UNDP (United Nations Development Programme) (2011), "Human development report 2011: Sustainability and equity: A better future for all", New York, NY: UNDP, Palgrave Macmillan. p.165.

UNDP (United Nations Development Programme) (2013), "Human development report 2013 - The Rise of the South Human progress in a Diverse World", The United Nations Development Programme, UN Plaza, New York, USA, Printed by Gilmore Printing Services Canada, pp. 146-147, 173, 196-197.

\section{ABOUT THE AUTHOR}

Dr Samia Satti Osman Mohamed Nour obtained her first degree (BSc Hons.) and second degree (MSc) in Economics from the University of Khartoum (Sudan) in 1994 and 1999 respectively, and her doctorate $(\mathrm{PhD})$ in Economics from the University of Maastricht (the Netherlands) in 2005. Currently, she is an affiliated researcher (and former Visiting Research Fellow and former PhD Fellow) at UNU-MERIT, School of Business and Economics, Maastricht University, the Netherlands.

\section{Transition to a} knowledge-based economy in the Arab region

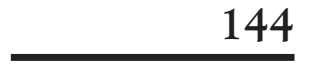


IJIKMMENA She is also an Associate Professor of Economics at the Department 3,2 of Economics, Faculty of Economic and Social Studies, Khartoum University, Sudan. Dr Nour's main research interests are in the fields of Economics, Economics of Technical Change, Macroeconomics, Microeconomics, Development Economics, Sustainable Development, Endogenous Growth, Human Capital and Labour Economics and Knowledge Economy. She has published several reports, discussions and working papers and has contributed to eight articles published in international refereed journals. 
